\title{
On Elves and Freethinkers: Criticism of Religion and the Emergence of the Literary Fantastic in Nordic Literature Dirk Johannsen
}

\begin{abstract}
In the late nineteenth century, the relationship between fictional literature and religion was up for debate. In the Nordic literary scene, this debate was triggered by Danish literary critic Georg Brandes in 1871, when he famously announced a turn towards critical realism. Fiction was identified as a possible link between secular and religious representations of reality, and modern literature was supposed to act as a catalyst for the criticism of religion. In the following years, literature became the medium to explore the 'problem of religion,' the utopia of an atheist society and the mysteries of the human mind. This article traces major theoretical impulses and their literary substantiations from 1870's literary realism to the emergence of the literary fantastic in the 1890s. In the literary fantastic, the criticism of religion became religiously productive. Anticipating the cognitive study of religion, folkloristics explained supernatural concepts as the natural result of ordinary mental mechanisms. This radical naturalism allowed for an inclusion of the supernatural in literary realism. The case example of Haugtussa (1895), a work by the Norwegian author Arne Garborg, shows the lasting re-configuration of the understanding of religion that gave way to a 'modern religiosity' based on fiction.
\end{abstract}

Keywords: Fiction and Religion, Fantastic Literature, Critical Realism, Folklore, Modern Breakthrough, Criticism of Religion, Theory of Religion, Conceptual History 


\section{Introduction: Religion and Modern Literature}

To literary theorist Tzvetan Todorov, fantastic literature is about modern realities. The fantastic is transitional in that it "occupies the duration of [...] uncertainty" regarding the nature of the narrated world. Not yet marvellous like the fairy tale, where the supernatural is an accepted part of the diegetic reality, and not yet disenchanted like literary realism, it illustrates the "hesitation experienced by a person who knows only the laws of nature, confronting an apparently supernatural event" (Todorov 1975, 25). In this way, the fantastic is defined by structural ambiguity: it is a literary genre which offers two conflicting interpretations of the described events, two options for the story's 'true genre'.

In Norway, the first major work of the literary fantastic in a strictly Todorovian sense was the epic poem cycle Haugtussa - A Story, written by Arne Garborg (18511924) in 1895. ${ }^{1}$ Haugtussa [The hill-elf] is the coming of age story of a girl who 'sees what is hidden in the night' (Garborg 1895a, 22). ${ }^{2}$ She experiences visions, speaks to the dead, and is taken into the mountain where she encounters elves and trolls. The folkloristic imaginaries that haunt the pages are dubious, not only to the reader but to the girl herself. The marvellous otherworld might well be the product of her delusional mind. Still, she decides to accept the supernatural as her reality.

Both in content and form, Haugtussa came as a puzzle to Garborg's contemporaries. ${ }^{3}$ Garborg was renowned as one of the leading naturalists of the Nordic literary scene. Most of his earlier novels were realistic explorations of current social issues, and many of them included profound attacks on Christianity and religion in general. Haugtussa was different, and difficult to classify: In 70 poems of various length, metre, and style, Garborg commingled fairy tales and psychological analysis, folksy regionalism and political symbolism, a tragic love story and an alternative take on religion (cf. Rynning 1951; Bø 2002). Clearly, it was not only a literary experiment in the line of a new romanticism. Haugtussa was meant as a fundamental contribution

\footnotetext{
${ }^{1}$ Cf. Svensen 1995, Omdal (2010, 120-125), and Schröder (2013, 145) regarding classifications of Haugtussa in the spectrum of Nordic fantastic literature.

${ }^{2}$ All translation from Scandinavian sources are mine and given in single quotation marks. All translations are literal, e.g. Norwegian religion or religiøsitet is translated as religion / religiosity, tro as belief etc. In case of longer translations including key terms or poetic expressions, the original passages are given in footnotes. The author would like to thank Markus A. Davidsen for substantive comments on an earlier draft of this article.

${ }^{3}$ See the discussion of reviews below.
} 
to a long ongoing debate on the nature of literature and religion. This debate had been initiated in the early 1870s, when the Danish literary critic Georg Morris Cohen Brandes (1842-1927) held a series of groundbreaking lectures on the Main Currents in Nineteenth Century Literature [Hovedstrømninger i det 19de Aarhundredes Litteratur] at the University of Copenhagen. Based on Left Hegelian thought, Brandes had suggested literature as a medium to debate socio-political 'problems,' religion being the most crucial of them (cf. Brandes 1872a, 1872b, 1873). Literature was supposed to substantiate the criticism of religion and to convey 'modernity' to a wide audience. To this end, the already entangled theoretical foundations of religion and fiction had to be adjusted (cf. Eßbach 2014, 457-459). Since religion was criticised for being based on made-up stories, a literature critical of religion had to provide more than alternative made-up stories: It had to become 'real' and 'alive,' as Brandes famously phrased it (Brandes 1872a). Thus, the 'problem of religion' affected the very core of the novelists' identity and work. The tremendous repercussions of the Brandesian criticism became known under the label of the Modern Breakthrough. ${ }^{4}$ As the programmatic foundation for a cultural-political movement, the so-called literary left, and, later on, as a focal point of demarcation, Brandes' lectures triggered pan-Scandinavian controversies on the interrelation of religion and fiction for thirty years to come. In literary journals ${ }^{5}$ and the newspapers' review sections, political and religious ideologies, academic theories and the literary market were pitted against each other. Literary works added to the dynamic, where new narrative styles and strategies interfered with chosen ideological positions. Brandes' critical realism soon gave way to diverse counter models: Nordic symbolism, attacks on positivism, and esoteric approaches to the human imagination were first conceived in explicit demarcation to or as a progressions of 'Brandesianism' (e.g. Jørgensen 1894). And while a form of "rational enchantment" can be seen as characteristic for European fin-de-siècle literature in general (cf. Saler 2004, 139), the pointed focus of the Nordic debate allows for detailed insights on how modern literature fundamentally changed the understanding of religion.

Historian Lucian Hölscher recently argued that "in the twentieth century religion became a concept, which entailed affirmation and denial of the existence of its

\footnotetext{
${ }^{4} \mathrm{~A}$ term first used by Georg Brandes (1883) in an attempt to consolidate an already disintegrating movement.

${ }^{5}$ The outline of the debates given below is largely based on a selection of these journals: the Danish Det nittende aarhundrede, Tilskueren, Ny Jord, and Taarnet as well as the Norwegian Samtiden and Syn og Segn.
} 
object at the same time" (Hölscher 2015, 75). This "ontological contradiction" encoded in the modern notion of religion is most apparent where religion and fiction interact in a way that literary fiction inspires religion, as it is quite common in new ("invented") religions (Cusack 2010). That certain literary works, such as Tolkien's Lord of the Rings, "do not claim to refer to the actual world" proves to be no obstacle for their use "as authoritative texts for actual religious practice" in fiction-based religions (Davidsen 2013, 378). Even "ironic imaginations" of a re-enchanted world (as captured in the XFiles slogan "I want to believe") might shape modern spirituality (Saler 2004, 146). This curious connectivity between fantastic literature and popular religion is apparent in scholarly perspectives as well: Both religion and the literary fantastic have often been described as results of a (Feuerbachian or escapist) projective imagination able to provide a form of 'meaning' (cf. Frenschkowski 2013, 554, and Koch 2006).

In the following, I argue that the wide acceptance of the ontological tension documented in these approaches emerged in the late nineteenth century, when the classical criticism of religion became religiously productive. The Nordic literary debate initiated by Georg Brandes is an example for a systematic, targeted and lasting reconfiguration of the domain of religion. It took place at the very periphery of the academic traditions featured in the established historiography of the academic study of religion (e.g. Sharpe 1975; Kippenberg 2002). The distinctive feature of the debate on religion and literature in the Nordic countries is the role of the academic study of folklore. Folkloristics were conceptualised as the study of the most basic and, from a naturalistic point of view, dubious forms of both poetry and belief. In 1888, Arne Garborg's long term friend, the folklorist Moltke Moe, argued for fiction and religion to be two sides of the same coin (Moe 1926 [1888]). His analysis of mythical narratives suggested supernatural concepts to function as 'poetic roots,' creating a structural ambiguity quite similar to what Todorov described as the fantastic "uncertainty". The idea that the 'primitive' imagination naturally provides the building blocks of both poetic and religious utterances, and that the interpretation of these utterances is a question of culture rather than nature resonated well among progressive writers. For Garborg and other novelists, religion became a choice rather than a matter of truth. Garborg's Haugtussa exemplifies this transition to a 'modern religiosity' (Garborg 1895b, 114), in which the poet takes the theologian's place. The development from 
critical realism, as an all-out attack on religion, to a form of fiction that would inspire future forms of religion was based on a consistent advancement of radical naturalism.

\section{The Modern Breakthrough: Literature, Religion, and a Call for Revolution}

To the young Georg Brandes, literature based on fantastic imaginations was a German felony. In the German romantic school, he argued in his famous lectures on the Main Currents in Nineteenth Century Literature, idealism had given way to a literary 'arbitrariness,' which the romantics simply declared 'to be the source of life and art, called for fantasy' (Brandes 1873, 49). For the Danish literary critic, the resulting literature had caused disastrous consequences in European political life. The unregulated imagination was an intellectual 'poison' $(1873,21)$, the seed of the reaction.

Starting in November 1871, Brandes' lectures unfolded as a Hegelian drama in which novelists and poets were the protagonists of European history. For Brandes, the development of modern literature was more than just a reflection of ongoing sociopolitical developments: by showcasing - or neglecting - social reality, works of literature provided crucial impulses that shaped modern Europe. A 'living' and 'real' literature could be a weapon, and the lectures were meant as a call to arms. Nordic literature in particular, Brandes stated, had become a 'sediment in the reactionary swamp.' Many of the famous Nordic authors, 'most of them pastors, sons of pastors, and theological candidates,' were still in the business of creating romantic fairy tale worlds to distract from the pressing social issues (Brandes 1872a, 14). It was about time to face reality and approach the problems of gender inequality, social disparity, and religion upfront. The time was ripe 'to usher in those currents which had their source in the revolution and visions of the future, and to stop the reaction wherever its historical task has come to an end' $(1872 a, 28)^{6}$. To this effect, romanticism had to be replaced by realism.

For left-wing liberals in all the Nordic countries, the Main Currents became epoch-making (Brøndsted 1984, 7). 'A no more dangerous book could fall into the hands of a fertile writer,' Henrik Ibsen praised the first edition of the lectures in 1872: 'It is one of those books that place a yawning gulf between yesterday and today' (Letter

\footnotetext{
${ }_{6}$ "Hovedarbeidet vil blive gjennem en Mangfoldighed af Canaler at lede de Strømninger, som have deres Udspring i Revolutionen og Fremskridtsideerne, herind og at standse Reactionen paa alle de Punkter, hvor dens Opgave historisk er endt."
} 
to Brandes, April 4, 1872: Bull 1939, 212) 7. The lectures announced a "revolution of the human spirit" (McFarlane 1979, 163) in which states would crumble and, again in the words of Ibsen, 'all religion will fall' (Letter to Brandes, February 17, 1871: Bull 1939, 206) ${ }^{8}$. Not only writers were enthused by the power and wit of the lectures. Almost immediately, Brandes' programme became the target of fierce counter-attacks from conservative politicians, academics, and theologians. This, in turn, made 'Brandesianism' an attractive form of youth protest. In Denmark, Brandes became an icon of the progressive student's association (cf. Knudsen 2008). In Norway, he 'became - by and large - the Norwegian youth's leader throughout the seventies' (Gran 1912, 4). Together with his brother Edvard Brandes, an Orientalist and later a Danish Minister of Finance for the Radical Left, Georg Brandes established a network of European intellectuals, a publication infrastructure, and links to the political left (cf. Stangerup 1946a; Knudsen 2008)..${ }^{9}$ Aspiring and already established writers, which in Norway included prominent public figures, such as Henrik Ibsen, Bjørnstjerne Bjørnsen, and Alexander L. Kielland, became part of the network and took up the task of providing a literature that would lead to the breakthrough of modernity (cf. Heitmann 2006).

\section{Georg Brandes on Religion and Realism}

In Brandes' lectures, religion was suggested to be the problem that required most immediate attention. Progress, he argued, was based on the principles of free thought, and religion undermined these principles by its very nature. Already in his debut, a Left Hegelian ('freethinkers') treatise against Dualism in our Latest Philosophy, Brandes had criticised recent applications of the protestant two kingdoms doctrine on the domains of science and religion (Brandes 1866). Theological attempts to reconcile knowledge and belief, he argued, tended to grant the latter artificial and arbitrary privileges. Social and scientific progress required a sense of reality, a free thought bound to one strict principle: 'The conviction that there are no enclaves, neither in

\footnotetext{
7 “Farligere bog kunde aldrig falde I en frugtsommelig digters hænder. Den er en af de bøger som sætter et svælgende dyb mellem igår og idag."

8 "Der vil falde større ting end den [staten]; al religion vil falde."

${ }_{9}$ On Brandes' popularity in Europe and beyond, cf. Harsløf 2004.
} 
nature nor history, that are not bound to the laws that govern history and nature [...]; the conviction of unity in nature, history, and all of existence [...]' (Brandes 1872b, 46) ${ }^{10}$.

To show how romantic writers and idealist philosophers had violated this principle and blurred the boundaries of reality, Brandes' lectures included an elaborate analysis of the interplay of religious perception and poetic representation of the world. With case studies stretching from Friedrich Schelling's 'reactionary' intuitionism to Joseph Görres's 'insane' mysticism (Brandes 1873), Brandes tried to show how the delusional character of romantic poetry connected to a delusional experience of reality. Based on Hyppolite Taine's naturalistic anthropology (On Intelligence, Taine 1871a), he outlined a unified theory of both supernatural fiction and religious experience. According to this theory, 'the self' is to be understood as 'an artificial product, based on the association of ideas' (Brandes 1873, 207) ${ }^{11}$. Human memory served Brandes as an obvious case in point: As a chain of remembered events, most memories may be based on actual experience. However, their sequence is a construct. False memories may enter the 'artificial chain'; elements of dreams, including fantastic and surreal visions, may associate themselves with real happenings and distort memories. Links in the chain of events might be forgotten, and fantasies, thoughts, and actual experience may get mixed up. Brandes suggested that this might have happened to Martin Luther, who gave an inner vision an external reality 'when he saw the devil in Wartburg Castle' (Brandes 1873, 207). Due to the 'fragile nature' of memory, blends of reality and fantasy would be remembered as if they were real and, subsequently, give rise to 'religious legends' and 'romantic poetry,' in which they are told as if they were real (1873, 205-208). To truly depict and impact reality, therefore, Brandes called on modern novelists to avoid 'arbitrariness' at any cost: there should be no enclaves in literature. In the sense of a critical realism, every link, every event described in a story had to be based on 'the conviction of unity in nature'. Fantastic or supernatural elements would have to be excluded or explained in their constructed character. In this way, the writer was to become a scientist, an analyst rather than a creative genius, as Norwegian literary critic Gerhard Gran summarised Brandes' approach: the 'novel

\footnotetext{
10 “[...] Overbevisningen om, at der hverken i Naturen eller i Historien gives Enklaver, der ikke ere underkastede de Love, som iøvrigt beherske Historie og Natur. [...] Overbevisningen om Naturens, om Historiens, om hele Tilværelsens Enhed [...]."

11 "[Altsaa i fornuftig Tilstand] er Jeget et Kunstproduct, et Product af Ideeassociationer."
} 
[would become] a scientifically reliable manual for the practical politician and reformer' (Gran 1912, 6).

\section{Religion in Critical Realism: The Story of the Freethinker}

Taken by Brandes' revolutionary rhetoric, progressive novelists faced a challenging task. To showcase the rather abstract 'problem of religion,' it had to be translated into a 'real' narrative conflict. In the end, it was a simple narrative scheme they established as a sort of "master plot" (Clark 1981, 9), replicated in dozens of variants: the freethinker story (Jones 1990, 30). The narrative setting was notoriously simple, as many novelists counted on the possibility of adaptions of their work for a (more lucrative) play. The protagonist would be a freethinker, often a former student of theology who had been abroad, read Feuerbach and Strauß, and became acquainted with 'modern' ways of thinking. Petty-minded, conservative Christians serve as antagonists. The latent conflict erupts as soon as the freethinker falls in love. Inevitably, the girl is pious and preferably the daughter of the local pastor. In this triangle of interests, heated arguments about the nature and the function of religion are exchanged (cf. Johannsen 2013). ${ }^{12}$ Believers and the solitary non-believer stand opposed as "two species" unable to find common ground (Dust [Støv], Bjørnson 1889, 373). The utter disregard for what seems 'devilish' to the one side and 'deluded' to the other is, at first, an intellectual problem (e.g. A Freehinker [Ein Fritenkjar], Garborg 1881). But with the girl at the centre of interest, the question of belief triggers a more fundamental issue: 'religion' encodes a restrictive way of life. The girl strives towards a traditional family life and inclusion into the Christian community. The freethinker presents an alternative outlook, where sex before marriage, travels to the European intellectual centres, intellectual growth, and odd jobs promise a richer, more 'real' experience of life. In this way the problem of religion is substantiated as an interpersonal conflict, a clash of lifestyles. Many of the early freethinker stories are confined to minor variations on the theme. In Karl Gjellerup's An Idealist (En Idealist, 1878), the freethinker has to deal with a conservative rival in love to win his girl. In Edvard Brandes' Breaking-off (Et Brud, 1885), the bride's father is the freethinker and forced to witness how his daughter dates a pastor. In

\footnotetext{
12 The model was Hans Christian Andersen's To Be or Not to Be [At Være eller Ikke Være] (1857), but the figuration used to trigger the plot (a student, a girl, and a representative of the conservative society) was already established in older works like Ludvig Holberg's Erasmus Montanus (1731).
} 
Alexander Kielland's Snow (Sne, 1886), the courted girl is the freethinker. In all cases, the problem remains the same: religious and free outlooks on life are incompatible, and religion is the fetter that prevents all progress.

This message gradually began to change during the 1880s. New writing styles were approached, notably a form of psychological or 'impressionistic' literary naturalism, altering the focus of the stories. With stronger internal focalisation and homodiegetic narrators, the social conflicts were toned down in favour of introspective reflections. The interpersonal conflict encoded as 'religion' evolved into an intrapersonal conflict. The freethinker himself became torn between his options. His own hopes for a family and social acceptance collide with prospects of discovering the world and being sincere about his beliefs. Step by step, the freethinkers' atheism evolved into a psychological challenge, famously phrased in Jens Peter Jacobsens Niels Lyhne:

[Niels Lyhne:] “[O]n the day when men are free to rejoice: 'There is no God!' on that day a new heaven and a new earth will be created as if by magic. [...] Don't you see what nobility it will give men when they are free to live their life and die their death, without fear of hell or hope of heaven, but fearing themselves, hoping for themselves? $[\ldots]^{\prime \prime}$

[Doctor Hjerrild:] “Then atheism will make greater demands on men than Christianity does. [...]"

[Niels Lyhne:] "Of course! [...] Neither this generation nor the next and not the next after that will be able to endure atheism [...]. [T]here is so much more than just the brain that has to be convinced, the blood and nerves, hopes and longings, and if there are dreams, they as well." (Jacobsen 1888 [1880], 150-152)13

In their self-analysis, the protagonists of the freethinker novels reflect on their constitution and heritage, the historical situation, and the social milieu as conditions

\footnotetext{
13 “'Men,' udbrød Niels Lyhne, 'fatter De da ikke, at den Dag, Menneskeheden fri kan juble: der er ingen Gud! den Dag skabes der som med et Trylleslag ny Himmel og ny jord. [...] Begriber De ikke, hvilken Adel det vil brede over Menneskeheden, naar den frit kan leve sit Liv og dø sin Død, uden Frygt for Helved eller Haab om Himmerig, men frygtende sig selv og med Haab til sig selv?' '[...] Atheismen vil jo komme til at stille større Fordringer til den, end Kristendommen gør. ' Naturligvis! [...] hverken denne Generation eller den næste eller den næste igen vil kunne bære Atheismen. [...] der er saa meget andet end Hjernen i et Menneske, der skal overbevises, Blodet og Nerverne, Haab og Længsler, ja om det saa er Drømmene, saa de ogsaa.'”
} 
that prevent them from fully embracing the Feuerbachian utopia. ${ }^{14}$ The problem of religion is internalised, and for the two most famous characters of Nordic naturalism it becomes a choice to either 'die standing' as an unbeliever - face 'the death, the difficult death' (Niels Lyhne, Jacobsen 1888, 267) ${ }^{15}$ - or to 'give up' and surrender to conformity. In Arne Garborg's decadence masterpiece Tired Men (Trætte mænd, 1891), protagonist Gerhard Gram still remains a non-believer but decides to join the church for the sake of conformity and mental hygiene. Step by step, the 'mind's natural dark side' (Brandes 1873, 23) ${ }^{16}$, where dreams faced an inner void and instincts clashed with values, became the new battlefield 'religion'.

\section{Critical Realism vs. the Popular Imagination}

The new predicament of style, focusing on internal conflict rather than social conflict, announced a turning point in the debates among intellectuals connected to the Modern Breakthrough. 'The Modern Breakdown,' as the gradual dissolution of the movement had polemically been called, took pace from the mid-1880s (Stangerup 1946b, 247-274). Quarrels between the proponents, the establishment of moderate left-wing political parties that disappointed the radical intellectuals, and a growing scepticism towards naturalistic conceptions of science reverberated on the literary programme (Thesen 1939, 16-24). Should a progressive literature be limited to describing the given reality, or should it rather explore alternative realities? Based on Brandes' literary history of Europe, Nordic novelists had developed a strong conception of living in a European periphery, and the literary journals of the time served the purpose of monitoring developments in the reference nations. French symbolism was discovered early on (Bourget 1889), and so were Spiritism and Theosophy (Bahr 1890). Academic psychology, perceived as an endeavour to tap into 'deeper layers' of the mind, was welcomed enthusiastically (Hamsun 1890). Eventually, it was believed, one would uncover the roots of the human imagination, which was both the core of the problem of religion and the tool every writer felt he had to control. The contemporary literary

\footnotetext{
${ }^{14}$ In Hippolyte Taine's History of English Literature, milieu (surrounding), heritage (race), and moment (epoch) were established as the conditioning factors of literary characters, to be covered in every naturalistic representation (cf. Taine 1871b, 10). Brandes' literary criticism was based on this conception.

15 "Og endelig døde han da Døden, den vanskelige Død."

16 "Aandens dunkle Naturside".
} 
critic Gerhard Gran, himself at the centre of debate in Norway, summarised the developments of the late 1880s and early 1890s:

Meanwhile, experimental psychology had produced a good deal of facts from the soul's hidden corners, so different from everyday phenomena that they seemed like impenetrable mysteries; the way from hypnosis and suggestion to telepathy and Spiritism was short, as it was prepared by 'the bankruptcy of science.' ${ }^{17}$ And now, everything that is be called mysticism or transcendentalism or religion [...] comes up again. (Gran 1897, 106) $)^{18}$

For the literary scene, the academic and religious developments pointed to a pressing problem with the Brandesian' approach: freethinker novels were hardly bestsellers. In contrast, the new 'mystical psychology' held an unparalleled promise to writers trying to make a living. In an attack on Brandes, Swedish author Ola Hansson envisioned how writers could enhance their productivity once they were able to "penetrate into the closed workshops, where the psycho-physiological wheelwork conducts its mysterious work' (Hansson 1890, 321) ${ }^{19}$. At the same time, these explorations could be used as a literary topic suited to cater to a new and 'better audience' (Hansson 1892, 361). Identifying supernatural mysteries as psychological 'phenomena,' writers from all factions discovered the religious traditions as a resource to the modern writer. Brandes' former student, the later Nobel laureate Karl Gjellerup, for example, systematically transferred the freethinker story into historical settings, where different religions would serve as a source for exoticism, wonder, and suspense. His love stories unfolded at times in antique Diana shrines, Hindu temples, and during Buddhist pilgrimages, then again at a haunted mill or among Gnostic heretics during the Middle Ages. The history of religions, a field made familiar by dozens of survey articles in the literary journals, could be used to create literary settings where conflicts develop 'organically' (Gjellerup 1895, xlvii). Ola Hansson promoted the comeback of the ghost story as an all-time classic. Again, this would not require any form of belief in the

\footnotetext{
17 A reference to Ferdinand Brunetière: "Après une visite au Vatican", Revue des Deux Mondes, January $1,1895$.

18 "Imidlertid havde den eksperimentelle psykologi fra sjælens skjulte kroge fremdraget en hel del kjendsgjerninger, som var saa forskjellige fra hverdagslivets fænomener, at de virkede som uigjennemtrængelige mysterier; veien fra hypnose og suggestion til telepati og spiritisme var kort, forberedt som den var ved 'videnskabens fallit'. Og alt det, som heder mystik og transcendentalisme og religion [...] trænger nu atter i forgrunden."

19 "at trænge ind i de endnu stængte verksteder, hvor de psycho-fysiologiske hjulkomplekser udfører dette hemmelighedsfulde arbeide".
} 
supernatural or the assumption of an intrinsic value of religion. The domain of the spirits had become the domain of the mind, and 'modern ghost stories' would simply document the conquest of new frontiers and [...] unexplored territories of human nature' (Hansson 1892, 360-61) ${ }^{20}$. Under the premise of 'animal magnetism' or 'hypnosis,' miracle stories could actually be written in a realistic framework. Folkloristic motifs that had long been used as a reservoir of allegories (e.g. Ibsen's Peer Gynt 1868) now came to connote internal 'powers'. Jonas Lie's famous opening: 'There is a troll in every man' (Lie 1891, 1) was more than a moral admonition. It was a reference to psychological forces whose potency was still indeterminate. The growing number of folktale collections were discovered as a considerable storytelling resource (Solberg 2007, 180-203). Of all disciplines, folkloristics soon proposed itself as the most notable provider of progressive poetic theory for a 'literature of the future' (Hansson 1890, 353; Vedel 1896, 416).

\section{The Popular Imagination: Fiction and Religion as Two Sides of the Same Coin}

Folkloristics was still a young discipline in the 1880s, but its genesis was eagerly monitored by the writers connected to the Modern Breakthrough. As the study of 'popular poetics,' it had an intimate connection to the writer's craft, and its subject area was defined precisely by the ambivalence of religion and fiction that the modernists struggled with.

During the late eighteenth and early nineteenth century, what before had been reports, memories, chatter, or old wives tales, was first transformed into 'folk-lore' (cf. Amundsen 1999). The term suggested diverse and heterogeneous forms of storytelling to be part of an anonymous (albeit national) 'oral tradition,' worthy of being collected, classified by genre and topic, published, and read. When the systematic collection and study of 'folktales' was initiated by the brothers Grimm in the early nineteenth century, it was based on a fundamental revaluation of 'superstition'. From a rational religious perspective, stories about elves, witches, and hidden people were popular superstitions disguised as poetry (cf. Amundsen 2005). The German national romanticists turned this logic around, and so did Adam Oehlenschläger in Denmark. The Brothers Grimm defined fairy tales and legends as two intertwined genres

20 "strandhug paa ukjendte kyster, der ikke kan andet end tilhøre menneskenaturens uopdagede land." 
characterised by a varying ratio of historicity and poeticity (Grimm 1816, v). Thus, the dubious content was identified as a form of poetry. 'Supernatural poetry' [overnaturlige Poesi], Oehlenschläger elaborated, was the result of the human imagination producing allegories meant as moral guidelines. Superstition was not the cause of the stories, but rather their effect: failing to understand the allegorical depths of their own stories, unlearned people had come to actually believe in elves (Oehlenschläger 1816, 3; cf. Anz 2005). The ambivalence between superstition and poetry fundamentally defined what was recognised as 'folktales'.

That folktales as such would qualify as religious narratives, however, was the 'modern' translation of the idea, cultivated early on in the Modern Breakthrough. In the Breakthrough's main journal The Nineteenth Century [Det Nittende Aarhundrede], Edvard Brandes in 1877 published a review of newly published collections of Danish legends, using the opportunity for an assault on theology. Since popular fantasies of 'house spirits, elves, ghosts, and revenants' (E. Brandes 1877, 335) ${ }^{21}$ show the legend's intimate connection to religious myths, he argued, the study of these two genres should not be separated. It would take a new discipline, a positive science of religion, to cover the broad field of 'the origin and development of myths, and their blending with other domains of human investigations of the mind' $(1877,336)^{22}$. In short: What theologians referred to as superstitions should be studied as religion, and religion, in the theologians' own terms, as superstition. Accordingly, theology as well as philosophy would become subject areas of a positive science of religion once it succeeded in unveiling the 'different layers with which conceptions of later times epic, moral, theological, liturgical, and philosophical - gird the primitive thought' $(1877,333)^{23}$.

This research programme was put into practice in 1886, when the Norwegian folklorist Moltke Moe became professor of folk tradition at the University of Kristiania (Oslo), a position that marked the institutionalisation of folklore in the Nordic countries. His 1888 lectures on The Mythical Mindset [Det mytiske tankesæt] were an attempt to uncover the mental dispositions that allowed for the creation of myths in

\footnotetext{
21 "Nissen, Bjærgfolkene, Spøgelserne og Gengangerne"

22 "Myternes Oprindelse og Udvikling og Sammenblanden med andre Gebeter for den menneskelige AandsForsken [bliver den positive Religionsvidenskabs Indhold...]."

${ }_{23}$ "de forskellige Hylstre, hvormed senere Tids Opfattelse, den episke, den moralske, den teologiske, den liturgiske og den filosofiske, have omgivet den primitive Tanke."
} 
general, from classical Greek and Old Norse mythology to the Christ myth. With Edward B. Tylor and Andrew Lang, Moe argued for the primacy of folktales in this endeavour:

Characteristic to myths and fairy tales, to folk belief and all of that, is the ongoing conflict with all the laws of logic and experience, a mad inversion of all of reality [...]. All of nature, animate or inanimate, is intellectually on equal terms with mankind; animals talk and marry humans; Gods and humans transform into animals; [...] we hear of most miraculous things, of horses and ships that travel through the air; of weapons that strike by themselves [...], hats that make invisible - etc., etc. (Moe 1926 [1888], 265) $)^{24}$

Moe approached the core question of the study of myth as one of psychology: 'How can something of this kind come up in human thought? How can we understand the mental condition that created this?' $(1926,266)^{25}$. His answer was based on the naturalistic anthropology that Georg Brandes had introduced to the Nordic debate on religion, interspersed with elements of evolutionism and positivistic poetics (cf. Scherer 1888). In the same way as memory can be seen as an 'artificial chain,' Moe argued, its 'close relative,' the human imagination, is the result of connections and syntheses of ideas: 'If a representation is reproduced inaccurately, or if the sequence between different representations is altered, new representations emerge.' Human fantasy should be seen as a form of 're-modelled reproduction. It does not create [...] but calls forth latent representations, combining them by association of ideas' (Moe 1926 [1888], 266) ${ }^{26}$.

Around a trigger that activates the imagination, distinct fantastic and imaginary memories become a nucleus of crystallisation - suddenly, by itself, involuntarily and

\footnotetext{
24 "Væsenseiendommelig for myter og for eventyr - likesom for folketro og alt slikt - er den gjennemgaaende strid med alle logikkens og erfaringens lover, en vild endevending av al virkelighet [...]. Hele naturen, den levende og den livløse, stilles intellektuelt paa like fot med mennesket; dyrene taler, og de gifter sig med mennesker; guder og mennesker forvandles til dyr [...]; vi hører om de merkværdigste underting, hester eller skibe som gaar i luft og land og vand, om vaaben som hugger av sig selv[...], hatter som gjør usynlig - osv. osv."

25 "Hvordan kan saadant opkomme i mennesketanken? Hvorledes skal vi forklare os den Aandstilstand som har skapt det?"

26 “Reproduceres en forestilling unøiaktig, eller ændres rækkefølgen mellem flere forestillinger, vækkes herved nye forestillinger"; "[det er fantasiens arbeide,] et omformende reproduksjonsarbeide. Fantasien skaper ikke, [...] den vækker alene slumrende forestillinger, og forbinder dem ved idéassociationer."
} 
uncalled for; unintentionally they call forth memory after memory, one representation after the other. $(1926,268)^{27}$

Most results of these 'mechanical' rearrangements would be passing imaginaries based on an accidental likeness, misperception, or personification. Storytelling skills provided, however, some of these nuclei could serve as poetic roots [digtrøtter]: the chain of ideas translates into a story. When shaped in a purposeful effort, they would become the foundation for both

myths and fairy tales, depending on whether they are religiously consolidated, under the influence of cult and faith, or poetic, under the influence of a conscious, active fantasy which connects and motivates. The religious consolidation [fortætning] produces myths, the poetic fairy tales. $(1926,268)^{28}$

It is interesting to note how closely the concept of poetic roots resembles the cognitive science of religion's recent approach to "counterintuitive concepts" (Boyer 2001), both regarding the process by which they 'come to mind naturally' and the many examples given by Moe, all of them counterintuitive in a strict sense. What cognitive theorist's regard to be a "hallmark of religion" (Pyssiäinen 2003) was first conceptualised as the hallmark of folklore. While the genesis of poetic roots is a psychological question, their consolidation as either religion or poetry is, in contrast, a historical one. As Edvard Brandes argued before, there is no structural, only an accidental difference between folktales and religious narratives. With their common 'cellular tissue' (Moe 1926 [1888], 282) referred to as poetic roots, primacy was given to the poetic use, but all poetry was potentially religious.

\section{A Fiction-Based Understanding of Religion: Arne Garborg's Haugtussa}

For Arne Garborg, Moltke Moe's theory of the naturalness of supernatural concepts was key to a new form of literature. His earlier works can be seen as a comprehensive approach to the Brandesian 'problems': A Freethinker (Ein Fritenkjar, 1878) took up the problem of religion, Peasant Students Bondestudentar (1883) the problem of class, Mannfolk (1886) the problem of the sexes, and With Mother (Hjaa ho mor, 1890) women's

\footnotetext{
27 “Omkring en foreteelse som sætter fantasien i svingning, skyter alskens fantasi- og forestillinsminder sammen som et krystallisationscentrum - pludselig, av sig selv, usøkt og uvillkaarlig; uten viljesimpuls vækkes minde efter minde, vækker den ene forstilling den anden."

28 "til myten og til eventyret, alt efter som de mytiske elementer fortætter sig religiøst, under indflydelse av kultus og tro, eller digterisk, under indflydelse av bevisst, aktiv fantasi, som binder sammen og motiverer. Den religiøse fortætning gir myter, den digteriske eventyr."
} 
emancipation. From the 1890s, 'progressive' approaches to religion in general and Christianity in particular began to dominate his literary production. In Tired Men (Trætte mænd, 1891), he internalised the social conflict 'religion' with a protagonist being torn between his contempt for religion and the emotional void of living without prospect. The inability to believe, combined with the urge for peace of mind, leads the protagonist to embrace Catholicism as a manifest absurdity. Peace (Fred, 1892) takes the perspective of a religious protagonist but mirrors the freethinker's life crisis when the prospect of salvation turns into an oversaturation of meaning, where everything seems as a message from God or the Devil, leading to the protagonist's suicide. Haugtussa (1895a) is, again, the account of a crisis. But this time the folkloristic frame provides a third ground. Stepping out of the strict dichotomy of religious vs. free thought, the protagonist, young Gislaug (called Veslemøy), is able to take control over her life. The poem cycle is crafted in detail according to the theory outlined by Moltke Moe, who was the first one Garborg asked to read and evaluate the drafts (Dale 1969). ${ }^{29}$

\section{The Freethinker becomes the Mountain Elf}

Haugtussa captures the "very heart of the fantastic" (Todorov 1975, 25). What is real, what is imaginary? The events described challenge the main character's and the modern reader's world view, creating a "hesitation common to reader and character" $(1975,41)$. Whether it is a poetic or a religious work is, in the terminology of Moltke Moe, not yet 'consolidated'. Already the opening poems reveal how academic theory and narrative schema interact to make the emergence (rather than the reality) of the supernatural plausible. The protagonist Veslemøy is introduced as a servant girl living on a farm in rural Norway. It is a life of hard and often monotonous work, and her imagination runs wild during her tasks. At the spinning wheel, as the second poem is called, she observes her cat sleeping by the stove and starts to speculate about his dreams: 'Maybe your thoughts / calm down / in old memories / [...] from the time you were a prince,' and she makes up a story of how a prince was cursed to live as a cat

\footnotetext{
${ }^{29}$ An early excerpt of Haugtussa was published in 1894 in the first issue of the journal Syn og Segn, for which Moe, Garborg, and the philologist Rasmus Flo acted as editors. Regarding Garborg's familiarity with the folkloristic endeavour cf. Liestøl 1921 and Djupedal 1961, 184-190. Regarding Moltke Moe's relation to Garborg cf. Fløtra 1995.
} 
(Garborg 1895a, 6-730). The imagination brings forth poetic roots, the transformation of man into animal, used to create stories. The local milieu accounts for typical traits of these stories: Living in poverty, ideas of elves or house spirits helping out and providing riches are common. Aspects of Veslemøy's heritage add to the picture: her grandmother is called crazy, her sister died a prostitute, and she herself is of weakest condition. These (naturalistic) ${ }^{31}$ premises account for Veslemøy's intense imagination and the type of poetic roots it produces. In the first longer poem, the genesis of legends is enacted by the fireside. Servants and children gather around Veslemøy, who tells the story of a man's encounter with the elves. The narrative event's ambiguity is embedded in the opening: The protagonist Helge Haaland spends a long evening in town (drinking?) and on his way home gets confused: 'The mountains seemed to stand amiss / directions seemed turned / the ground was a lake / lakes were the ground / the sea was a mountain ridge / and south was north. // He had forgotten where he lived' $(1875 a, 12)^{32}$. Stumbling through the night, Helge encounters a farm unknown to him and enters into a splendorous parlour where he meets a stunningly beautiful girl and her parents. Before he knows, food is served and the parents offer him their daughter's hand. But when they later on approach the bridal bed, Helge discovers her true nature. She is one of them, an elf bearing a cow's tail. In shock, he pulls his knife (steel banishes the otherworld) and everything gets black until he awakens 'with an aching head,' in the mud, from now on longing for his missed love.

The story depicts the legend's style and plot in detail, including the high degree of discontinuity of the situational dimensions, where most causal links between events remain open to debate (cf. Johannsen 2011). An element of doubt is included in the narrative structure, and Garborg makes use of it to introduce the supernatural - as one interpretation. It is the audience, in this case the fictional audience of farm workers and children gathered around Veslemøy, who have to decide whether the events are to be believed or to be enjoyed as fiction.

In the following poems, the routines of daily life constantly trigger Veslemøy's imagination. During the day she anthropomorphises all she sees; during the night she

\footnotetext{
30 "Kan henda dine Tankar / seg svæver linnt til Ro / i gamal Minne-Krins, / som stilt i Hop seg sankar / fraa den Tid, du var Prins?"

${ }^{31}$ Again based on Taine's conception of literary naturalism, cf. Taine 1871b, 10.

32 "Det var som Fjelli dei hadde flutt seg; / det var som Leiderne hadde snutt seg; / og Jord var Vatn, og Vatn var Jord, / og Hav var Fjellgard, og Sud var Nord. // Han hadde gløymt, kor han heime budde".
} 
dreams of elves. Finally, her deceased sister appears in her dream, announcing how Veslemøy will see 'what is hidden in the night'. It is 'the heaviest burden,' as it will

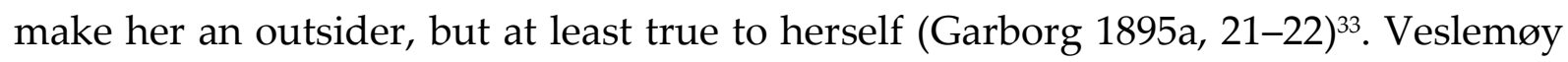
feels that she has to make a choice. Are her visions real after all? Should she fight them? She decides to accept: 'I'd rather see / with open eyes / than go through life / blind and deaf / without discerning what is true' $(1895 a, 37)^{34}$. The naturalistic frame remains untouched. By deciding to believe in what seems real and right to her, Veslemøy chooses life as an outsider.

As in the freethinker stories, the narrative schema contrasts 'two species' of man. Whereas the protagonist in Garborg's first freethinker novel would have the impression that everyone else is deluded, 'as if they were taken into the mountain' (Garborg 1881, 76), Veslemøy is actually 'taken in' and therefore isolated. But the story is no longer about social or intellectual truth. Being Haugtussa, only true to herself, the poems follow her through three years in which she falls in love and is rejected. The account of the lovelorn girl might well be read as a symbolic account of a depression, but it is written as a journey through the otherworld. Only by the very end of the cycle, she overcomes what might be trolls or her own fears, and finds either God or herself, steps into the light or leaves her mental strife behind to come to peace. Fantastic in the Todorovian sense, " $[\mathrm{t}]$ he ambiguity is sustained to the very end of the adventure: reality or dream? truth or illusion?" (Todorov 1975, 25). It is up to the reader to 'consolidate' the story.

\section{Haugtussa's Consolidators: Fiction Perceived as Religion}

Haugtussa's reception in later literary studies was mostly confined to psychological and developmental analyses (cf. Andersen 2012, 267), locating the work in the context of the author's 'religious struggles' (Finn 1972) and the general turn from literary naturalism to symbolism or a 'new romanticism' (cf. Mannsåker 1961). ${ }^{35}$ Highlighting symbolic and psychological aspects as the evident foundation of Haugtussa conforms

\footnotetext{
33 "Du hev den tyngste Lagnad, / som nokon her kan faa. / Det som i Natt seg løyner, / det skal du skilja og sjaa."

34 "Aa helder vil eg / med Augo sjaa, / en dauv og blind / gjenom Verdi gaa / og ikkje det sanne skilja!"

35 The latter classification is somewhat misleading, as 'new romanticism' was mostly used as a polemical category for a new 'reaction' and was rejected by many writers identified as new romanticists (cf. Vedel 1889, 283-284).
} 
to modern reading habits. The immediate reception, however, was different, at least until 1898, when Edvard Grieg transformed the poems into a song cycle that would determine its affiliation with national high culture. In early reviews, symbolistic and psychological understandings were not absent, but the borders between psychological and parapsychological, between symbolic and religious interpretations were not yet set. Was it a regression into reactionary romanticism (Haug 1899, 43)? Or rather 'a symbol for [Garborg's] liberation from being "taken in" by the materialistic spirit of the time's short-sighted logic' (Hedmarkens Amtstidende, May 14, 1895) ${ }^{36}$ ? Many critics were happy to announce that the notorious freethinker Garborg had finally found his way back to Christian faith, while others assumed a more occult agenda: critic Lars Eskeland found Haugtussa to be a spiritist pamphlet. While visiting Garborg, Eskeland had gained the impression that the author would claim revelations from 'dead monks and farm boys' (Haukenæs 1898, 309), an allegation that seemed somewhat plausible, as Garborg had recently published several articles on Spiritism and Theosophy (e.g. Garborg 1893). Contemporary Garborg-expert Hjalmar Christensen saw Haugtussa as an illustration of the depths of the interpersonal mind, 'the secret relation between nature, the living earth, it's visible and invisible life, and man, as a child of this earth, who stands, half torn, in wonder [...] facing intuitions of dark memories of his origin' (Christensen 1895, 46) ${ }^{37}$. Others straight out rejected any symbolism: '[I]t might be better to take [Haugtussa] in a more literal sense. There are actually independent, personal spiritual powers that are evil around us; [...] we can call them trolls or devils' (Den 17de Mai, January 3, 1899) ${ }^{38}$. But was the story meant to confirm their existence or rather meant as a warning against the 'delusions that superstition creates' (Tromsø Stiftstidende, June 6, 1895)? It certainly seemed hard to say what Haugtussa was really about: 'There is a double meaning throughout' (Den 17de Mai, May 7, 1895). ${ }^{39}$

\footnotetext{
36 "et Sympol paa hans Udfrielse fra sin Bergtagenhed i den materialistiske Tidsaands kortsynte Logik." 37 "det hemmelige forhold mellem naturen, mellen den levende jord, dens synlige og usynlige liv, og mennesket, der er barn af denne jord, men halvt løsrevet sig og stiller sig undrende, iagttagende til hvad det ser, og hvad det i dunkel erindring om sin herkomst aner og lytter sig til".

38 "Eg tykkjer no likevel, det er betre aa taka det meir bokstaveleg. Der er verkeleg sjølvstendige, personlege aandsmagter, som er vonde. [Det er ikkje berre menneskje, som er vondt, der er eit rike av vonde aander ikring oss,] ein kann kalla dei troll eller djevlar."

${ }^{39}$ Strikingly, many commentators from all factions agreed on an interpretation according to which the final transformation, with Veslemøy stepping out of the shadows and into the light, meant her death a thought absent in later literary criticism as it collided with the theological master narrative of how the
} 
Todorov summarised the nature of the literary fantastic with regard to the reader's aesthetic response: “The fantastic [...] implies an integration of the reader in the world of the characters; that world is defined by the reader's own ambiguous perception of the events narrated" (Todorov 1975, 31). The nature of the fictional world is indetermined, and when Veslemøy decides to take a stand, the reader is provoked to do the same. Every respective decision made in the "act of reading," however, limits the range of interpretation to one specific understanding of the meaning and genre of Haugtussa (cf. Iser 1978). For Arne Garborg, the indeterminate nature of the narrated world and the main character's arbitrary choice was a reflection of the indeterminate meanings given to one's own imagination and life.

\section{Arne Garborg on 'modern religiosity'}

The Modern Breakthrough was initiated with the aim to exchange the religious foundation of romantic literature for the naturalistic framework of 'free thought': 'One ends up realising that he who is no longer able to believe in a child's manner has to think like a man' (Garborg 1889 [1881], 74) ${ }^{40}$. As the protagonist of dozens of stories, the lonesome freethinker's ambition to live without religion resulted in the question on the social and psychological possibilities of such a life. 'Religion, which for so long had been the unfortunate's refuge, can no longer help us; we cannot believe in it,' Garborg noted in 1890 (1967 [1890], 93) ${ }^{41}$, but the Brandesian' naturalism had left the freethinker haunted by dreams and imaginations it could not account for. A revaluation of religion first became possible when naturalistic anthropology provided frameworks to explain the genesis of supernatural concepts as natural products of mental faculties. Detached from Christianity, the term would denote any meaning given to one's inward reality. For many Nordic writers, the philosophy of Schopenhauer and, discovered by Georg Brandes in 1889, Friedrich Nietzsche became iconic representations for the consequences of radical naturalism (Brandes 1889). One has to 'create meaning for one's own life,' Arne Garborg quoted Nietzsche in 1895, and

modernist writers underwent a temporary religious crisis (Lillehei 1916, 157) culminating in a 'return to religion'.

40 "Man ender med å erkjenne, at den som ikke lenger kan tro på barnets vis, han må tenke på mannens."

${ }_{41}$ "Religionen, som så lenge var de ulykkeliges tilflukt, kan ikke lenger hjelpe oss; vi kan ikke tro på den." 
to start 'believing in life' (Garborg 1895c, 35942; 1895b). For Garborg, this was the turning point. A consequent naturalistic criticism of traditional religion would actually lead to a new form of religion:

And there we have the modern religiosity, as I guess it has to be established. We call our mystery life, lacking a better word. [...] 'Believing in life' is the religion of thinkers, giving their personalities all the support these peaceless characters can possibly obtain. (Garborg 1895b, 114) ${ }^{43}$

In Haugtussa, he examined this "vision of life "in practice," by the "realities" the poetic work creates for us' (Вø 2008, 171). Garborg himself commented on Haugtussa:

All the fear therein ('Haugtussa' has a good deal) wants something light, noonday and wide skies, much sun and much power [...]: 'Religion' is about the innermost feelings, instincts, the innermost soul's self-preservative drive; its form - well, it depends on your character. (Letter to Jonas Lie, June 4, 1895, Garborg 1954, 320) (4 $^{4}$

The character of Veslemøy reminds of Henrik Ibsen's freethinking Nora, who had to realize that she did not "even know what religion is" but was confident enough to find out "if it is right for me" (A doll's house, Ibsen 1899 [1879], 33445; cf. Garborg's discussion of the statement 1889,43$)$. Veslemøy was the freethinker of the 1890s, able to decide on what to believe and how to live, without the need to explain her decision. With collective tradition and truth exchanged for individual life and meaning, the ambiguous imagination and its manifestation, fantastic fiction, became the legitimate foundations of a modern religiosity. ${ }^{46}$

\footnotetext{
42 "skapa sjølv meining i sitt liv".

43 "Og så har vi den moderne religiøsitet, - således som jeg tror den må begrunnes. - Vi kaller vårt mysterium livet, i mangel av et bedre ord. [...] 'Troen på livet' er de tenkendes religion, og gir dem all den personlighetens støtte som disse fredløse naturer i det hele er i stand til å oppnå."

44 "Al den Angst der inde ('Haugtussa' har jo en Del af den) vil ha noget lyst, høi Dag og vid Himmel, megen Sol og megen Kraft [...]: 'Religion', det er den inderste Følesessag, Instinktsag, den inderste Sjælens Selvopholdelsesdrift; dens Former - naa ja, de er ogsaa helt afhengige af Personligheden." 45 " [...] jeg véd jo slet ikke riktigt, hvad religionen er. [Når jeg kommer bort fra alt dette her og blir ensom, så vil jeg undersøge den sag også. Jeg vil se, om det var riktigt, hvad presten Hansen sagde, eller ialfald] om det er riktigt for mig."

${ }^{46}$ In his later works, Garborg approached Christianity from this revised perspective on the nature of religion. He argued that the ontological devaluation of the gospel as fictional, based on the Christ myth theory elaborated by David Friedrich Strauß and Bruno Bauer, did not necessarily diminish the value of the New Testament as a source of Christian faith and true values (Garborg 1906). Here, Garborg actually suggests Christianity as a fiction-based religion in the strict sense (cf. Davidsen 2013).
} 


\section{Conclusion: Naturalism, the Literary Fantastic and Modern Religiosity}

The modern literary fantastic, as exemplified by Haugtussa, turned out to be a subgenre of critical realism. In Moltke Moe's naturalistic anthropology, religion and poetry were responses to supernatural imaginaries produced by ordinary mental processes. They were no longer questions but answers, reactions to the mechanisms of the inner life. Accordingly, Garborg's conception of 'modern religiosity' was based on a radical naturalism. The iconic entity of Nordic folklore, the elf, was an appropriate icon for this theory-inspired and fiction-based religiosity, in which the freethinker would cherish life by deciding on its meaning. Of course, the anticipation of elf-identifications among later Tolkien religionists is just a curiosity. But Haugtussa and the Nordic debate are characteristic for some general trends in fin-de-siècle approaches to religion.

The consistent development from literary realism to the literary fantastic illustrates the pivotal role literature played in the dynamics of changing understandings of religion (cf. Grieser 2006, 181). By substantiating academic theories and cultural ideologies in the form of narratives, literature acted as a catalyst, providing prototypical representations of how religion might look, feel, and be performed. In line with the Brandesian objectives, Garborg saw it as the true merit of the poet to give 'flesh and blood' to philosophical abstractions (Garborg 1873, 9). The modernist freethinker stories put flesh on the classical criticism of religion and the subsequent reductive theorising. Where ontological naturalism had exposed the freethinker to an existence without meaning and, later on, to an uncontrollable mind, he was left to believe in his own poetic imagination. In literature, the criticism of religion became religiously productive.

The impact of literary works and theory pertains not only to modern forms of religiosity, but to modern notions of religion as well. With a "symptom of doubt" (Hölscher 2015, 81) encoded in the notion of religion, poetry could be revalued as a genuine expression of the sacred, and religion could be criticised as a misguided poetic creation (Eßbach 2014, 457-58, 689-90). Critics and novelists systematically explored this relation and established a lasting affinity of fiction and religion: The fantastic was crafted in accord with theories of religion; the popular poetic forms defined as folklore became prototypical religious narratives. Today, narratological tools developed in the study of fantastic literature prove useful in the analysis of religious narratives (e.g. Feldt 2011). In the cognitive study of religion, counterintuitive concepts are now 
perceived to be characteristic for religious, rather than folkloristic narratives. Accordingly, current analyses of the cognitive foundations of religion seem especially fruitful, where they deal with 'popular' forms of religiosity (cf. Slone 2004) or are applied to the study of modern speculative fiction (e.g. Zunshine 2008). The perceived connectivity of 'religious' and 'fantastic' narratives still documents the theoretical implications given to them in late nineteenth century literature.

\section{References}

Amundsen, Arne Bugge. 1999. “Med overtroen gjennom historien. Noen linjer i folkloristisk faghistorie 1730-1930." In Hinsides. Folkloristiske perspektiver på det overnaturlige, edited by Siv Bente Grongstad, Ole Marius Hylland and Arnfinn Petersen, 13-49. Oslo: Spartacus Forlag. Amundsen, Arne Bugge. 2005. "Mellom inderlighet og fornuft." In Norges religionshistorie, edited by Arne Bugge Amundsen, 243-294. Oslo: Universitetsforlaget.

Andersen, Hans Christian. 1857. At være eller ikke være. Copenhagen [Kjøbenhavn]: C.F. Reitzel. Andersen, Per Thomas. 2012. Norsk Litteraturhistorie (2 utg.). Oslo: Universitetsforlaget.

Anz, Heinrich. 2005. “'Die übernatürliche Poesie'. Märchenpoetik und Märchenbearbeitung in Adam Oehlenschlägers Märchenanthologie Eventyr af forskiellige Digtere (1816)". Text $\mathcal{E}$ Kontext, vol. 27/1-2: 92-115.

Bahr, Herman 1890. "Buddha i Europa." In: Samtiden. Populært tidsskrift for litteratur og samfundsspørgsmaal 1: 401-404.

Bjørnson, Bjørnstjerne. 1889. På guds veje. Copenhagen [Kjøbenhavn]: Gyldendal.

Bø, Gudleiv. 2002. Veslemøys verden. Veiviser i 'Haugtussa'. Oslo: Aschehoug.

Bø, Gudleiv. 2008. “Må me lerkesongen tru?” In Haugtussa, by Arne Garborg, 171-181. Bergen: Vigmostad \& Bjørke.

Bourget, Paul. 1889. “Charles Baudelaire.” Ny Jord. Nordisk Tidsskrift for Literatur, Videnskab og Kunst: 238-256.

Boyer, Pascal. 2001. Religion explained. The evolutionary origins of religious thought. New York: Basic Books.

Brandes, Edvard. 1877. “Nye Samlinger af Folkepoesi.” Det Nittende Aarhundrede, 1/1877: 319336.

Brandes, Georg. 1866. Dualismen i vor nyeste philosophie. Copenhagen [Kjøbenhavn]: Den Gyldendalske Boghandel (F. Hegel).

Brandes, Georg. 1872a. Hovedstrømninger i det 19de Aarhundredes Litteratur. Forelæsninger: Emigrantlitteraturen. Copenhagen [Kjøbenhavn]: Den Gyldendalske Boghandel (F. Hegel). 
Brandes, Georg. 1872b. Forklaring og Forsvar. En Antikritikk. Copenhagen [Kjøbenhavn]: Den Gyldendalske Boghandel (F. Hegel).

Brandes, Georg. 1873. Hovedstrømninger i det 19de Aarhundredes Litteratur [2]. Den Romantiske Skole i Tydskland. Copenhagen [Kjøbenhavn]: Den Gyldendalske Boghandel (F. Hegel).

Brandes, Georg. 1883. Det moderne gjennembruds mænd. En række portræter. Copenhagen [Kjøbenhavn]: Den Gyldendalske Boghandel (F. Hegel).

Brandes, Georg. 1889. “Aristokratisk radikalisme." Tilskueren. Maanedsskrift for literatur, samfundsspørsmaal og almenfattelige videnskabelige skildringer 7: 565-613.

Brøndsted, Mogens, ed. 1984. Nordische Literaturgeschichte, Bd. 2: Von 1860 bis zur Gegenwart. München: Fink.

Christensen, Hjalmar. 1895. Nordiske Kunstnere. Oslo [Kristiania]: Aschehoug.

Clark, Katerina. 1981. The Soviet Novel. History as Ritual. Chicago: University of Chicago Press.

Cusack, Carole M. 2010. Invented Religions: Faith, Fiction, Imagination. Surrey: Ashgate.

Dale, Johs. A. 1969. “Garborg i arbeid med 'Haugtussa'”. In Garborg-studiar by Johs. A. Dale, 73-85. Oslo: Det Norske Samlaget.

Davidsen, Markus Altena. 2013. "Fiction-based religion: Conceptualising a new category against history-based religion and fandom." Culture and Religion. An Interdisciplinary Journal 14/4: 378-395.

Davidsen, Markus Altena. 2014. The Spiritual Tolkien Milieu: A Study of Fiction-Based Religion. Leiden University: PhD Dissertation.

Djupedal, Reidar. 1961. “Etterord.” In Haugtussa og andre dikt, by Arne Garborg, 165-198. Oslo: Noregs Boklag.

Eßbach, Wolfgang. 2014. Religionssoziologie I. Glaubenskrieg und Revolution als Wiege neuer Religionen. Paderborn: Fink.

Feldt, Laura. 2011. "Fantastic Re-Collection: Cultural vs. Autobiographical Memory in the Exodus Narrative." In Religious Narrative, Cognition and Culture. Image and Word in the Mind of Narrative, edited by Armin W. Geertz and Jeppe Sinding Jensen, 191-208. Sheffield Oakville: Equinox.

Finn, Thorn. 1972. Arne Garborg og Kristendommen. Brytninger mellom tro og tvil. Oslo: Aschehoug.

Fløtra, Jorunn. 1995. Moltke Moe som Folklorist. Oslo: Aschehoug.

Frenschkowski, Marco. 2013. "Phantastik und Religion." In: Phantastik. Ein interdisziplinäres Handbuch, edited by Hans Richard Brittmacher and Markus May, 553-561. Stuttgart: J.B. Metzler.

Garborg, Arne. 1873. Henrik Ibsen's ,Keiser og Galiläer.' En kritisk studie. Oslo [Christiania]: Aschehoug. 
Garborg, Arne. 1881. Ein Fritenkjar. Forteljing. Oslo [Kristiania]: Cammermeyer.

Garborg, Arne. 1883. Bondestudentar. Forteljing. Bergen: Fr. Nygaards Forlag.

Garborg, Arne. 1889. Fri Forhandling. Ymse Stykkje um tru og tanke. Bergen: Mons Litleré.

Garborg, Arne. 1890. Hjaa ho Mor. Bergen: Mons Litleré.

Garborg, Arne. 1891. Trætte Mænd. Oslo [Kristiania]: Aschehoug.

Garborg, Arne. 1892. Fred. Oslo [Kristiania]: Aschehoug.

Garborg, Arne. 1893. "Lidt Spiritisme." Samtiden. Populært tidsskrift for litteratur og samfundsspørgsmaal 3: 1-7; 55-79; 146-153.

Garborg, Arne. 1895a. Haugtussa. Forteljing. Oslo [Kristiania]: Aschehoug.

Garborg, Arne. 1895b. "Troen paa livet." Samtiden. Populært tidsskrift for litteratur og samfundsspørgsmaal 6: 9-16.

Garborg, Arne. 1895. “Friedrich Nietzsche.” Syn og Segn 2: 93-105, 341-359.

Garborg, Arne. 1906. Jesus Messias. Oslo [Kristiania]: Aschehoug.

Garborg, Arne. 1954. Mogning og Manndom. Brev II. Edited by Johs. A. Dale and Rolv Thesen. Oslo: Aschehoug.

Garborg, Arne. 1967. Artiklar. Oslo: Noregs Boklag.

Gjellerup, Karl. 1895. Hans Excellence. Indleded ved en efterskrift til mine dramer. Copenhagen [Kjøbenhavn]: Gyldendal.

Gran, Gerhard. 1897. "Biografiske skisser. I. Arne Garborg." Samtiden. Populært tidsskrift for litteratur og samfundssporgsmaal 8: 97-107.

Gran, Gerhard. 1912. Religiøs uro. Streiflys. Oslo [Kristiania]: Aschehoug.

Grieser, Alexandra. 2006. "'Die Götter sind eine Funktion des Stils.' Schöne Literatur als Medium der Religionskritik am Beispiel des Drama in Leuten von Fernando Pessoa." Zeitschrift für Religionswissenschaft 14/2: 157-182.

Grimm, Jacob and Wilhelm Grimm. 1816. Deutsche Sagen. Berlin: Nicolaische Buchhandlung.

Hamsun, Knut. 1890. “Fra det ubevidste sjæleliv.” Samtiden. Populært tidsskrift for litteratur og samfundsspørgsmaal 1: 325-334.

Hansson, Ola. 1890. “Literære Produktionsmaader.” Samtiden. Populært tidsskrift for litteratur og samfundsspørgsmaal 1: 314-320.

Hansson, Ola. 1892. “Causerier i mystik." Samtiden. Populært tidsskrift for litteratur og samfundsspørgsmaal 3: 352-360.

Harsløf, Olav (ed.). 2004. Georg Brandes og Europa. Forelæsninger fra 1. internationale Georg Brandes Konference, Firenze, 7-9 november 2002. Copenhagen: Museum Tusculanums Forlag. Haug, A. 1899. Norges nyere litteratur. Fire foredrag. Elverum: Østlandske Tidendes Bogtrykkeri. Haukenæs, Th.S. 1898. Lys og mørke. Skildringer fra det norske folkeliv. Bergen: C. Floor. 
Heitmann, Annegret. 2006. “Die Moderne im Durchbruch (1870-1910)." In Skandinavische Literaturgeschichte, edited by Jörg Glauser, 183-229. Stuttgart: J.B. Metzler.

Ibsen, Henrik. 1899. Samlede værker Bd. 6. Copenhagen [København]: Gyldendalske Boghandels Forlag (F. Hegel).

Iser, Wolfgang. 1978. The Act of Reading: A Theory of Aesthetic Response. Baltimore: Johns Hopkins.

Jacobsen, Jens Peter. 1888. Samlede Skrifter. Andet Bind. Copenhagen [Kjøbenhavn]: Gyldendalske Boghandels Forlag (F. Hegel).

Johannsen, Dirk. 2011. "No time to philosophize. Norwegian oral tradition and the cognitive economics of belief". In Past Minds. Studies in Cognitive Historiography, edited by Luther Martin and Jesper Sörensen, 77-88. London: Equinox.

Johannsen, Dirk. 2013. Erschriebene Religion. Die Vielfalt der Stimmen in den Religionserzählungen des modernen Durchbruchs In Alternative Voices. A Plurality Approach for Religious Studies, edited by Afe Adogame, Magnus Echtler and Oliver Freiberger, 36-55. Göttingen: Vandenhoeck \& Ruprecht.

Jones, Walton Glyn, ed. 1990. Georg Brandes. Selected Letters. Norwich: Norvik Press.

Jørgensen, Johannes. 1894. “Symbolisme.” Taarnet. Illustreret Maanedsskrift for Kunst og Literatur, $51-56$.

Kippenberg, Hans G. 2002. Discovering Religious History in the Modern Age. Princeton: Princeton University Press.

Knudsen, Jørgen. 2008. GB. En Georg Brandes Biografi. Copenhagen [København]: Gyldendal.

Koch, Anne. 2006. "'Religionshybride' Gegenwart.' Religionswissenschaftliche Analyse anhand des Harry-Potter-Phänomens." Zeitschrift für Religionswissenschaft 06/1, 1-23.

Lie, Jonas. 1891. Trold. En tylft eventyr. Copenhagen [Kjøbenhavn]: Gyldendalske Boghandels Forlag.

Liestøl, Knut. 1921. “Arne Garborg og den norske folkediktingi.” Syn og Segn 27: 3-14.

Lillehei, Ingebrigt. 1916. "The Language and Main Ideas of Arne Garborg's Works." Publications of the Society for the Advancement of Scandinavian Study 3/2: 134-199.

Mannsåker, Jørund. 1951. “Omkring Garborg-jubileet.” Vinduet 5/1: 41-50.

McFarlane, James. 1979. “Cultural Conspiracy and Civilizational Change: Henrik Ibsen, Georg Brandes, and the Modern European Mind." Journal of European Studies 9: 155-173.

Moe, Moltke. 1926. “Det mytiske tankesæt. Efter forelæsninger fra 1888.” In Moltke Moes samlede skrifter, ed. by Knut Liestøl, Vol. II, 265-283. Oslo: Aschehoug.

Oehlenschläger, Adam. 1816. Eventyr af forskiellige Digtere: sammendragne og oversatte, med Bemærkninger. Copenhagen [Kiøbenhavn]: Gyldendal. 
Omdal, Gerd Karin. 2010. Grenseerfaringer: fantastisk litteratur I Norge og omegn. Bergen: Fagbokforlaget.

Pyysiäinen, Illka. 2003. "Counterintuitiveness as the hallmark of religiosity." Religion 33/4: 341-355.

Rynning, Christian. 1951. Haugtussa. Ein Stilanalyse. Oslo: Det norske samlaget.

Scherer, Wilhelm. 1888. Poetik. Berlin: Weidmann.

Schröder, Stephan Michael. 2013. "Skandinavien." In Phantastik. Ein interdisziplinäres Handbuch, edited by Hans Richard Brittnacher and Markus May, 112-117; 144-150. Stuttgart: J.B. Metzler.

Sharpe, Eric John. 1975. Comparative Religion. A History. London: Duckworth.

Slone, D. Jason. 2004. Theological Incorrectness. Why Religious People believe What They Shouldn't. Oxford: Oxford University Press.

Solberg, Olav. 2007. Inn i eventyret. Norsk og europeisk fortljekunst. Oslo: Cappelen Akademisk Forlag.

Stangerup, Hakon. 1946a. Kulturkampen. Første Del: 1872-1877. Copenhagen [København]: Gyldendalske Boghandel - Nordisk Forlag.

Stangerup, Hakon. 1946b. Kulturkampen. Anden Del: 1878-1883. Copenhagen [København]: Gyldendalske Boghandel - Nordisk Forlag.

Svensen, Åsfrid. 1995. “'Alt dult I myrkre vankar.' Haugtussa som fantastisk litteratur." Norsk Litterær Årbok: 76-87.

Taine, Hippolyte. 1871a. On Intelligence. London: L. Reeve and Co.

Taine, Hippolyte. 1871b. History of English Literature. Vol 1. Edinburgh: Edmonston and Douglas.

Thesen, Rolf. 1939. Arne Garborg. Europear og Jærbu. Oslo: Aschehoug.

Todorov, Tzvetan. 1975. The Fantastic: A Structural Approach to a Literary Genre. Cleveland: Case Western Reserve.

Vedel, Valdemar. 1889. “En Replik.” Ny Jord. Nordisk Tidsskrift for Literatur, Videnskab og Kunst: 281-286.

Zunshine, Lisa. 2008. Strange Concepts and the Stories they Make Possible. Baltimore: The Johns Hopkins University Press. 